DR. GIULIANO DEGRASSI (Orcid ID : 0000-0002-9368-2113)

Article type : Journal of Applied Microbiology

\title{
Screening of bacterial endophytes as potential biocontrol agents against soybean
}

\section{diseases}

Karla Bianca de Almeida Lopes ${ }^{1}$; Valéria Carpentieri-Pipolo ${ }^{3}$; Djordje Fira ${ }^{4}$; Pedro Alberto

Balatti $^{5}$, Silvina Marianela Yanil López ${ }^{5}$, Thiago Henrique Oro ${ }^{1}$; Eduardo Stefani Pagliosa ${ }^{1}$, Giuliano Degrassi2*

${ }^{1}$ Post Graduation Program in Agronomy; Agronomy Department, Universidade Estadual de Londrina, Rodovia Celso Garcia Cid, Pr 445 Km 380, PO Box 10.011; 86.057-970, Londrina, PR, Brazil.

2 International Center for Genetic Engineering and Biotechnology, Polo Cientifico Tecnologico, Godoy Cruz 2390, C1425FQD, Buenos Aires, Argentina degrassi@icgeb.org ${ }^{3}$ Embrapa Trigo Rodovia BR-285, Km 294 PO Box 3081, 99050-970, Passo Fundo, RS Brazil; valeria.carpentieri-pipolo@embrapa.br

${ }^{4}$ University of Belgrade, Faculty of Biology, Studentski trg 16, 11000 Belgrade, Serbia; fira@bio.bg.ac.rs

${ }^{5}$ Centro de Investigaciones de Fitopatología, Fac. de Ciencias Agrarias y Forestales - UNLP, Avenida 60 y calle 119 S/N, (1900) La Plata, Bs As, Argentina; pbalatti@gmail.com

*Corresponding author

\section{Running title: Antagonistic soybean bacterial endophytes}

This article has been accepted for publication and undergone full peer review but has not been through the copyediting, typesetting, pagination and proofreading process, which may lead to differences between this version and the Version of Record. Please cite this article as doi: $10.1111 /$ jam.14041

This article is protected by copyright. All rights reserved. 


\section{ABSTRACT}

Aims. This research was aimed at identifying and characterizing endophytic microorganisms associated to soybean that have antimicrobial activity towards soybean pathogens.

Methods and Results. Soybean plants were collected from field trials in four locations of southern Brazil that were cultivated with conventional (C) and transgenic glyphosate-resistant (GR) soybeans. Endophytic bacteria isolated from roots, stems and leaves of soybeans were evaluated for their capacity to inhibit fungal and bacterial plant pathogens and thirteen microorganisms were identified with antagonistic activity. Approximately 230 bacteria were isolated and identified based on the 16S rRNA and rpoN gene sequences. Bacteria isolated from conventional and transgenic soybeans were significantly different not only in population diversity but also in their antagonistic capacity. Thirteen isolates showed in vitro antagonism against Sclerotinia sclerotiorum, Phomopsis sojae and Rhizoctonia solani. Bacillus sp. and Burkholderia sp. were the most effective isolates in controlling bacterial and fungal pathogens in vitro. Extracts and precipitates from culture supernatants of isolates showed different patterns of inhibitory activity on growth of fungal and bacterial pathogens.

Conclusions. Bacillus sp. and Burkholderia sp. were the most effective isolates in controlling fungal pathogens in vitro, and the activity is mainly due to peptides. However, most of the studied bacteria showed the presence of antimicrobial compounds in the culture supernatant, either peptides, bacteriocins or secondary metabolites.

Significance and Impact of the Study. These results could be significant to develop tools for the biological control of soybean diseases. The work brought to the identification of microorganisms such as Bacillus sp. and Burkholderia sp. that has the potential to protect 
crops in order to enhance a sustainable management system of crops. Furthermore, the study provides the first evidences of the influence of management as well as the genetics of glyphosate resistant soybean on the diversity of bacterial endophytes of soybean phytobiome.

Keywords: Biological control, endophytes, antagonism, plant-bacteria association, glyphosate-resistant soybean, soybean pathogens, crop protection.

\section{INTRODUCTION}

Soybean production in tropical areas increased in the last decades and its growth should continue increasing in spite of the climatic conditions that frequently lead to the development of diseases and or stresses, which can have profound impacts on yield. Around 40 diseases are frequently affecting fields cultivated with soybean, which are caused by fungi, bacteria, nematodes and viruses. Among them, the most important ones are bacterial blight caused by Pseudomonas savastanoi pv. glycinea, bacterial pustule by Xanthomonas axonopodis pv. glycines, white mold by Sclerotinia sclerotiorum, Phomopsis seed decay by Phomopsis sojae and Rhizoctonia root rot by Rhizoctonia solani. Soybean cultivation is expanding to new areas and soybean monoculture led to the increase of diseases that caused reductions in yield.

Sustainable management systems are key tools to maintain yield over the years, in such systems plants might be protected from diseases or other adversities with environmentally friendly tools that have low impact on the production and also on the environment. As a consequence, the interest for biological control of plant pathogens is increasing and strategies of biological control have been proposed and developed (Jamalizadeh et al. 2008; Pimenta et al. 2010; Syed Ab Rahman el al., 2018) as well as biopesticides formulations (Hynes and Boyetchko 2006). In addition varieties with resistance 
against diseases (Ramalingam et al., 2017) and efficient agronomic management were also adopted. In this scenario, biocontrol emerges not only as a reliable alternative to chemical pesticides, but it also may provide control of diseases that cannot be managed by other strategies, such as in the case of phytopathogenic bacteria (Berić et al. 2012), providing opportunities for a rationale and safe crop management.

Protection of plants from pathogens can be achieved either through an antagonistic interaction or by activating mechanisms such as the induced systemic resistance (Mohammad et al. 2009; Verhagen et al., 2010; Bae et al., 2011). Among the microorganisms that can protect plants against pathogens are the endophytes (Ryan et al., 2008). These microorganisms inhabit plant intercellularly and are therefore less exposed to environmental stresses then the rhizobacteria. Also for this reason they have been studied for their potential as biocontrol agents (Kuklinsky-Sobral et al., 2004; Berg and Hallmann, 2006; Melnick et al., 2011). Recently it has also been shown that they enhance plant growth and health (Taghavi et al. 2009; Dalal and Kulkarni 2013), although they could be potential biocontrol agents of diseases by antagonizing with bacterial and fungal plant pathogens (Ryan et al., 2008).

Bacteria belonging to the genera Bacillus, Streptomyces, Pseudomonas, Burkholderia and Agrobacterium have been the biological control agents predominantly studied and increasingly marketed (Fravel 2005). The antifungal and antibacterial activity of these microorganisms against phytopathogens might be due to the production of either proteins, peptides, lipopeptides, bacteriocins or secondary metabolites, and for each of them there are specific procedures that can be used to purify and characterize them (Vater et al. 2002; Montesinos 2007; Maksimova et al. 2011).

The aim of this study was to identify and characterize bacterial endophytes isolated from conventional as well as glyphosate-resistant soybean with the ability to antagonize fungal and 
bacterial pathogens of soybean. In this regard, we identified the strains with antagonistic activity towards bacterial and fungal plant pathogens.

\section{MATERIAL AND METHODS}

Plant Material. Plant samples were collected from field experiments conducted by the Brazilian Agricultural Research Corporation (Embrapa Soybean) in four sites, Ponta Grossa (PR), Guarapuava (PR), Cascavel (PR) and Campos Novos (SC) in Brasil where six soybean cultivars including non-transgenic (C) and glyphosate-resistant (GR) transgenic ones were sown, as previously reported by de Almeida Lopes et al (2016). BRS 245RR and BRS 133 were related genotypes used as sources for the isolation of endophytes. BRS 245RR was genetically engineered to tolerate glyphosate, e.g. Roundup Ready ${ }^{\circledR}$ and is essentially derived from the protected nontransgenic cultivar BRS133 (Brazilian Agricultural Research Corporation, Embrapa Soybean). The other cultivars included in this study were TMG 801 (non transgenic) and NK7059 (GR) Roundup Ready® resistant grown in Cascavel (PR), and BRQ09-11694 (C) and the BMX Energia (GR) grown in Guarapuava (PR) and Campos Novos (SC). The breeding line BR Q09-11694 (C) was also developed by Embrapa Soybean. BMX Energia (GR), TMG 801 (C) and NK 7059 Roundup Ready® (GR) were developed by the seed companies Brasmax Genetic, Tropical Breeding e Genetic and Syngenta Seeds LTDA, respectively.

The experimental design had a completely randomized factorial approach and each cultivar, at each site, had three replicates. Endophytic bacteria were isolated from roots, stems and leaves of soybean cultivars. Soil management, sowing, glyphosate and other chemicals used to control weeds applications, sampling and harvesting criteria were those reported by de Almeida Lopes et al., (2016). 
Isolation of endophytic bacteria from roots, leaves and stems. Samples of leaves, roots and stems, collected in triplicate, were disinfected superficially with serial washes through the following procedure: $75 \%$ ethanol for $1 \mathrm{~min}$, sodium hypochlorite $(2.5 \% \mathrm{HCl})$ for $4 \mathrm{~min}$, ethanol for $30 \mathrm{~s}$, and finally 3 rinses in sterile, phosphate buffer solution (PBS - $1.44 \mathrm{~g}$ of $\mathrm{Na}_{2} \mathrm{HPO}_{4}, 0.24 \mathrm{~g}$ of $\mathrm{KH}_{2} \mathrm{PO}_{4}, 0.20 \mathrm{~g}$ of $\mathrm{KCI}, 8.00 \mathrm{~g}$ of $\left.\mathrm{NaCl}, \mathrm{pH} 7.4\right)$. Endophytes were isolated following the procedure previously reported (de Almeida Lopes et al., 2016). Briefly, the samples were weighed and macerated in $1 \mathrm{ml}$ PBS buffer. The obtained suspensions were used for counting and isolating from the serial dilution $\left(1: 10, \mathrm{v} \mathrm{v}^{-1}\right)$ in PBS to $10^{-3}$ dilution. Subsequent dilutions, in three replica vials for each dilution, were inoculated onto solid culture media. Two culture media were used: Nutrient Agar (NA) amended with 20\% glycerol, and Trypticase Soy Agar (TSA). After 7-8 days incubation al $28{ }^{\circ} \mathrm{C}$, single colonies were streaked onto the same media used for the isolation and incubated for $2-3$ days at $30{ }^{\circ} \mathrm{C}$ before being stored at $4{ }^{\circ} \mathrm{C}$. The isolates were then grown in the same liquid media and stored at $-80{ }^{\circ} \mathrm{C}$ in $15 \%$ glycerol.

In order to control the efficiency of disinfection, processed tissue samples were placed onto Petri dishes and the absence of fungal as well as bacterial growth monitored.

Bacterial and fungal pathogens of soybean. The antagonistic activity of endophytic bacteria was determined against three bacterial and three fungal phytopathogens, $X$. axonopodis pv. glycines IBSBF327-NCPPB3658, X. axonopodis pv. glycines IBSBF333NCPPB3659, P. savastanoi pv. glycinea IBSBF 355, and S. sclerotiorum, P. sojae and $R$. solani, respectively. The bacteria of this study were obtained from the Culture Collection of the International Centre for Genetic Engineering and Biotechnology (ICGEB, Buenos Aires, Argentina) and the fungi from the Culture Collection of the CIDEFI at the University of La Plata (La Plata, Argentina). Experiments with pathogens were performed in Argentina under 
controlled laboratory conditions upon approval from the national competent authority (SENASA). Bacterial strains were maintained on NA medium and were grown in LB broth at $30^{\circ} \mathrm{C}$. Fungi were grown and maintained on potato dextrose agar (PDA) and incubated at room temperature $25 \pm 2^{\circ} \mathrm{C}$.

In vitro antagonistic activity of endophytes. The antifungal activity of 223 endophytic bacterial strains was determined by inoculating the bacterial strains on NA and KB agar medium and incubating at $30^{\circ} \mathrm{C}$ for $24 \mathrm{~h}$. Then $1 \mathrm{~cm}^{2}$ of agar was cut out with a sterile blade, placed upside down onto the surface of a PDA Petri dish previously spreaded with the fungal mycelium grown for 4-5 days liquid culture. Plates were incubated at $25-28^{\circ} \mathrm{C}$ for $4-5$ days.

Antibacterial activity of isolated endophytes was determined by using cell-free culture supernatants and modified well-diffusion assays that were run on Petri dishes filled with 15 $\mathrm{ml}$ of soft LB medium, previously inoculated with $70 \mu 1$ of the culture of indicator strain containing approximately $1 \times 10^{6} \mathrm{CFU} \mathrm{ml}^{-1}$ (Koo et al., 2012; Balouiri et al. 2016). Each well was filled with $50 \mu \mathrm{l}$ of cell-free culture supernatant previously filter-sterilized. A clear halo formed around the bacterial agar indicated antagonistic activity towards the fungal target, while around the well indicated the presence of antibacterial activity in the supernatant (Figure 1A). Isolates were classified into: (-) no halo, or lack of activity; (+) small halo (1-2 mm), little activity; $(++)$ medium halo $(3-4 \mathrm{~mm})$, median activity; $(+++)$ large halo (greater than $4 \mathrm{~mm}$ ), high activity.

Genotypic characterization of bacterial endophytes. Only thirteen isolates among the 223 tested against the phytopathogenic fungi and bacteria used in this study showed in vitro antagonisms toward the pathogens, although with different pattern and antimicrobial activity. In order to make a preliminary identification of the isolates, the genomic DNA was extracted 
with PureLink ${ }^{\circledR}$ Genomic DNA Mini Kit (Life Technologies, Carlsbad, California). PCR amplification of $16 \operatorname{SrRNA}$ fragments was obtained by using primers $338 \mathrm{~F}$ and $778 \mathrm{R}$ or $27 \mathrm{~F}$ and 800R as described previously (Lane 1991; Anzai et al. 1997; Rösch and Bothe 2005; Xing et al. 2008). PCR amplification of rpoN was obtained by using primers rpoB1206 (5'ATC GAA ACG CCT GAA GGT CCA AAC AT-3') and rpoBR3202 (5'-ACA CCC TTG TTA CCG TGA CGA CC-3'). The predicted fragments to be amplified based on 16SrRNA sequence were 440 and $773 \mathrm{bp}$, respectively. The predicted fragment to be amplified based on rpoN sequence was 1200 bp. PCR products were purified with PureLink ${ }^{\circledR}$ Quick Gel Extraction Kit (Life Technologies) and sequenced by Macrogen (Macrogen Inc., Seoul, South Korea). Sequences were annotated at the NCBI database and also compared by means of the Basic Local Alignment Search Tool BLAST program (National Center for Biotechnology Information) available at the National Center for Biotechnology Information website (http://www.ncbi.nlm.nih.gov/BLAST) with the available sequences of microorganism at the NCBI database. Based on this preliminary approach we selected the sequences of the type strains that prove to be highly homologous to the sequences of the organisms isolated in this work. We made a multiple alignments using the (Clustal W) and then built a phylogenetic tree using neighbor-joining algorithm (Jukes-Cantor model) using the software MEGA 6.0 (www.megasoftware.net/). The reliability of the neighbor-joining tree was estimated by bootstrap analysis with 1,000 pseudoreplicate data sets.

Nucleotide sequence accession numbers. The $16 \operatorname{Sr} R N A$ and $r p o N$ nucleotide sequences have been deposited in GenBank, the NIH genetic sequence database. Accession numbers of 16SrRNA sequences of isolates from 1 to 13 are MH251720, MH251721, MH251722, MH251723, MH251724, MH251725, MH251726, MH251727, MH251728, MH251729, MH251730, MH251731, MH251732, respectively. RpoN sequences accession numbers are: 
MH286543 for isolate 1, MH286544 for isolate 2, MH286545 for isolate 3, MH286546 for isolate 5, MH286547 for isolate 7, MH286548 for isolate 8, MH286549 for isolate 9, MH286550 for isolate 10, MH286551 for isolate 11, MH286552 for isolate 12, and MH286553 for isolate 13.

Isolation of antimicrobial compounds from culture supernatants. Bioactive lipopeptides from tested strains were isolated as previosly described (Vater et al. 2002; Mandal et al., 2013; Smyth et al., 2010). Thirteen endophytic bacterial strains were grown in $200 \mathrm{ml}$ of NB shaking at $200 \mathrm{rpm}$ for $24 \mathrm{~h}$ at $30{ }^{\circ} \mathrm{C}$. Bacterial cells were removed by centrifugation at $5,000 \mathrm{xg}$ for $20 \mathrm{~min}$ and $4^{\circ} \mathrm{C}$ and lipopeptides were collected from cell-free supernatants by precipitation. Thus, they were acidified by adding $5 \mathrm{M} \mathrm{HCl}$ to $\mathrm{pH} 2.0$ and incubated at $4^{\circ} \mathrm{C}$ in order to precipitate lipopeptides that were recovered by centrifugation at $13,000 \mathrm{xg}$ for $15 \mathrm{~min}$ at $4^{\circ} \mathrm{C}$. The resulting pellet was extracted with methanol for $2 \mathrm{~h}$ under continuous stirring. Methanol was filtered to remove insoluble material and then evaporated. The fractions obtained were dissolved in $100 \mathrm{mM}$ phosphate buffer $\mathrm{pH} 7.0$ and their inhibitory activity on phytopathogens was evaluated.

Another method used to precipitate antimicrobial peptides was by adding ammonium sulfate. Cell-free supernatants of bacterial cultures were processed as follows. Ammonium sulfate was slowly added to the supernatant up to $60 \%$ of saturation (Shi et al., 2015; Soundra Josephine et al. 2012). The sample was kept overnight at $4^{\circ} \mathrm{C}$ while stirring and centrifuged for $30 \mathrm{~min}$ at $5,000 \mathrm{xg}$ at $4^{\circ} \mathrm{C}$. The pellet was recovered and re-suspended in $100 \mathrm{mM}$ sodium phosphate buffer $\mathrm{pH} 7.0$ and the antagonistic activity against phytopathogens was evaluated.

This article is protected by copyright. All rights reserved. 
Organic solvent-soluble molecules were collected from culture supernatants by adding ethyl acetate. Cell-free culture supernatants were acidified with $0.1 \%(\mathrm{v} / \mathrm{v})$ of acetic acid and extracted twice with the same volume of ethyl acetate. The organic phase was separated from the water phase, dried and re-suspended in $100 \mathrm{mM}$ sodium phosphate buffer $\mathrm{pH}$ 7.0.

\section{In vitro antimicrobial activity of isolated compounds.}

Antifungal activity. Mycelial growth inhibition was estimated by the radial growth inhibition assay. Previously we divided the agar (PDA) Petri dish in two sections and, to avoid mixing the two compartments, a strip of $1 \mathrm{~cm}$ long-agar, from the center, was cut out and removed . One piece of $1 \mathrm{~cm}^{2}$ of PDA agar inoculated with a fungus was transferred into the center of each Petri section. One section was spread with $0.5 \mathrm{ml}$ of bacterial endophyte culture extracts and another one with $100 \mathrm{mM}$ phosphate buffer pH 7.0 as control (Figure 1B). After 7 days at $25^{\circ} \mathrm{C}$ the percentage of growth inhibition (PGI) was calculated using the formula: PGI $(\%)=$ (KR-R1) / KR x 100, where KR is the colony diameter and represents the distance (measured in $\mathrm{mm}$ ) from the point of inoculation to the colony margin in the half plate used as the control, and R1 is the colony diameter, the distance of fungal growth from the point of inoculation to the colony margin on the half plate treated with the extract or precipitated material from the cell-free supernatant (see Figure 1B).

Antibacterial activity. Inhibition of bacterial growth was determined by modified welldiffusion assays that were run on Petri dishes filled with $15 \mathrm{ml}$ of soft LB medium, previously inoculated with $70 \mu 1$ of the culture of indicator strain containing approximately 1 $\mathrm{x} 10^{6} \mathrm{CFU} \mathrm{ml^{-1 }}$ (Koo et al., 2012; Balouiri et al. 2016). Fifty $\mu \mathrm{l}$ of the desired extract was poured on $5 \mathrm{~mm}$ diameter wells made in the medium with the bottom parts of $200 \mu$ pipette tips. Hundred mM sodium phosphate buffer $\mathrm{pH} 7.0$ was used as negative control, plates were 
incubated overnight at $30^{\circ} \mathrm{C}$ and inhibition was calculated by measuring halos around wells (see Figure 2).

Data Analysis. Data from CFU g ${ }^{-1}$ fresh weight were transformed into $\log _{10}$. The statistical design was a factorial where environments (herbicide management) were considered fix effects and cultivars random effects. The diversity and evenness indexes differences were statistically evaluated by means of ANOVA. For data with a normal distribution ANOVA and Tukey's test at 5\% probability were performed. Data not showing normal distribution were subjected to Kruscal-Wallis variance analysis and means were compared by Dunn's test $(\mathrm{p}<0.05)$. Analysis of data was performed using the software Statistical Analysis computer package, version 9.1, of SAS (SAS Institute, Inc., Cary, NC). The genus composition of the endophytes communities were performed using the sequence analysis of the 16S rRNA gene. The sequences were entered into BioNumerics v. 7.5 (Applied Maths) as fasta files and the analysis of bacterial endophytes sequences was performed.

The efficiency of mycelia growth inhibition (PGI\%) for the extracts or precipitates from cellfree culture supernatants of bacterial endophyte was estimated by t test, confidence intervals of $95 \%$ and $99 \%$.

\section{RESULTS}

Antagonistic bacterial endophytes. A total of 223 endophytic bacteria were isolated from non-transgenic (C) and glyphosate-resistant transgenic (GR) soybeans grown during the 2012/2013 season, in four locations of southern Brazil. The number of isolates recovered was 85 in Cascavel (PR), which represents $38.1 \%$ of the total, 81 in Ponta Grossa (PR) $(36.3 \%$ of the total), 26 in Guarapuava (PR) (11.7\% of the total) and 31 in Campos Novos (SC) $(13.9 \%$ of the total). Regarding the part of the plant from which they were isolated, $58(26.0 \%)$ 
bacteria were recovered from stems, 59 (26.5\%) from leaves and 106 from roots $(47.5 \%)$. One hundred and thirty isolates were obtained from GR soybean (58.3) and 93 (41.7\%) from non-transgenic soybean (de Almeida Lopes et al, 2016).

The antagonistic activity of all 223 isolates was tested by challenging them against the soybean fungal pathogens $S$. sclerotiorum, $P$. sojae and $R$. solani and the bacterial pathogens $X$. axonopodis pv. glycines and $P$. savastanoi pv. glycinea. The selection of isolates for this study was based on growth inhibition of at least one of the assayed pathogen; only 13 isolates (5.8\%) inhibited the growth of pathogens in vitro and fungi were found to be more sensitive than bacteria when grown in the presence of the isolates. Bacteria with antimicrobial activity were representatives of the following genera: Enterobacter, Agrobacterium/Rhizobium, Kosakonia, Variovorax, Bacillus, Burkholderia, Pantoea and Serratia (Table 1, Figure 3). Only the representatives of the genus Burkholderia inhibited growth of all fungal pathogens tested, though with different efficiency (Table 1), suggesting that they might have or use different mechanisms and/or molecules (Table 1), while representatives of the other genera among the 13 selected isolates also had antagonist activity against $S$. sclerotiorum but with lower efficiency in vitro (Table 1). While several of the isolates that inhibited growth of $S$. sclerotiorum and P. sojae were recovered exclusively from non-transgenic soybean like Enterobacter ludwigii, Burkholderia sp. and Bacillus sp., some others were isolated only from GR soybeans like Agrobacterium tumefaciens/Rhizobium sp., Kosakonia cowardii, Serratia marcescens and Pantoea sp. and some others from both, non-transgenic and transgenic plants (Enterobacter sp. and Variovorax sp.) (Table 1).

Identification of isolates. Species with antimicrobial activity were identified based on two sequences, a partial 16SrRNA gene sequence and $r p o N$. While the former represents the conserved genes of the protein synthesis machinery of bacteria, rpoN codes $\sigma^{54}$ of RNA 
polymerase and is like the 16SrDNA a universal molecule used for taxonomical studies. The preliminary identification of isolates based on the partial sequence of the 16SrDNA, indicated that four were representatives of Enterobacter, three of Burkholderia and there was one representative of each of the following genera: Kosakonia, Agrobacterium/Rhizobium, Pantoea, Variovorax, Serratia and Bacillus (Fig 3A). Analysis of identity among species based on the data from sequencing of the 16SrRNA gene amplicon of bacterial isolates was also performed and the results are shown in Fig.3B. In order to provide a more accurate identification of the isolates of this study, the sequencing of another gene was included in the analysis; we successfully amplified and sequenced $r p o N$ of all the isolates, except two. In the analysis of the sequences we included those of the type strains of each genus, which were compared with rpoN sequences of the isolates. Results are presented in Fig 4. The phylogenetic tree confirmed that four isolates were representatives of the genus Enterobacter (isolates 1, 2, 3 and 13), but only one was identified as Enterobacter ludwigii (isolate 1). Both 16SrRNA and rpoN gene sequences suggested that the isolated Bacillus sp. belongs to the $B$. subtilis species complex and, within this complex, to the operational group of $B$. amyloliquefacies. All Burkholderia isolates (8, 9 and 10) were found to belong to the $B$. cepacia complex. However the rpoN sequences showed the highest homology with rpoN of B. cenocepacia type strain, suggesting the three Burkholderia isolates could belong or be closely related to this species. Isolate 12 , whose $16 \mathrm{SrDNA}$ sequence was homologous to Serratia, was identified as $S$. marcescens, however we did not include this in Fig. 4 because the rpoN sequence of the type strain was not available. Then the isolate of Pantoea (isolate 11) was identified as $P$. vagans. The $16 \mathrm{SrDNA}$ sequence of isolate 5 suggested it was Enterobacter, however, based on the rpoN sequence, it was identified as Kosakonia cowandi, a species that was initially considered Enterobacter.

This article is protected by copyright. All rights reserved. 
Characterization of antimicrobial activity. The in vitro antimicrobial activity tests (Table 1) showed that Bacillus (isolate 7) and Burkholderia (isolates 8, 9 and 10) were the most effective in controlling the three fungal pathogens, however with different patterns of activity: Bacillus (isolate 7) was active only against S. sclerotiorum, while among the three Burkholderia, isolate 8 was active against all three fungal pathogens, isolate 9 only against $S$. sclerotiorum and $R$. solani, and isolate 10 against $S$. sclerotiorum and P. sojae. All other isolates had lower activity against the fungal pathogens. No one of the thirteen isolates showed activity towards bacterial pathogens in the test conditions, except a weak activity of Enterobacter ludwigii against $X$. axonopodis IBSBF327 (Table 1).

A preliminary characterization of the putative antagonistic molecules that prevented growth of plant pathogens was performed. Cell-free culture supernatants of the thirteen endophytic bacteria were extracted with ethyl acetate or methanol or precipitated with ammonium sulfate and screened for antimicrobial activity. Results of tests against phytopathogenic fungi like $S$. sclerotiorum (Fig. 5A), P. sojae (Fig. 5B) and R. solani (Fig. 5C) and against phytopathogenic bacteria $X$. axonopodis pv. glycines and $P$. savastanoi pv. glycinea (Fig. 6) showed results significantly different from those obtained in vitro and reported in Table 1. Results reported in Fig. 5 and 6 and regarding the antifungal and the antibacterial activity of extracts and precipitates from cell-free culture supernatants are also summarized in Table 2 and 3 , respectively, and are based on the intensity of the activity.

Studies regarding antagonism as well as antimicrobial activity of extracts and precipitates from cell-free culture supernatants were performed on Petri dishes, as shown in Fig. 1. Under such conditions, whether the extraction was performed with methanol, ethyl acetate or precipitated with ammonium sulfate, results showed that extracts and precipitates from cellfree culture supernatants of Bacillus (isolate 7) and Burkholderia (isolates 8, 9 and 10) were the most effective in controlling the three fungal pathogens and that all the extracts had 
antagonistic activity against them (Fig. 5). It is noteworthy that although isolate 7 , a representative of the genus Bacillus, had no activity against $P$. sojae and $R$. solani in vitro (Table 1), a MeOH extract and/or the NH4-S precipitate inhibited both P. sojae (Fig. 5B) and R. solani (Fig. 5C). However the EtAc extract had no activity on fungal growth (Fig. 5). The extracts or precipitates from culture supernatants of any of the Burkholderia isolates were the most active ones towards phytopathogenic fungi (Fig. 5A), confirming the results presented in Table 1 for in vitro antagonism. The culture supernatant of Bacillus sp. (isolate 7) and Burkholderia spp (isolates 8,9 or 10) prevented growth of pathogenic fungi within a range of $71.4 \%$ to $100 \%$. Furthermore, the percentage of inhibition exerted by any of the isolates was the same whether the active molecules were extracted with methanol or precipitated with ammonium sulfate.

Enterobacter, Variovorax and Serratia marcescens had a median activity in vitro only against S. sclerotiorum (Table 1). However extracts or precipitates from culture supernatants had activity also against $P$. sojae but no activity against $R$. solani (Fig. 5).

When we considered the antimicrobial activity against bacterial pathogens (Figures 2 and 6), we found that extracts or precipitates from cell-free culture supernatants of Bacillus and the three Burkholderia had a strong activity while, among the other isolates, only Pantoea showed a moderate activity of the ethyl acetate extract towards Xanthomonas (61Xag; Fig. $6)$.

Regarding the activity of Burkholderia sp. and Bacillus sp. culture extracts and/or precipitates against bacterial pathogens, all of them inhibited growth of at least one isolate of $X$. axonopodis pv. glycines (Xag) or P. savastanoi pv. glycinea (Psg). Furthermore, almost all precipitates and extracts from Bacillus sp. culture supernatants antagonized both Xag and Psg (Fig. 6 and Table 3). Among the Burkholderia, although isolate 8 was the only one able to antagonize all three fungal pathogens, when cell-free culture supernatant extracts and 
precipitates were tested against bacterial pathogens there was no activity against any of the pathogen (Fig. 6 and Table 3). On the other hand Burkholderia isolates 9 and 10 showed a significant activity, although with a different pattern based on the different precipitate or extract (Table 3). Importantly, isolate 10 showed strong activity against all bacterial pathogens when the ethyl acetate extract was used. Isolate 9 had a significant activity against both Xag when the ammonium sulfate precipitate was used, and a strong activity when the ethyl acetate extract against $P s g$ was used.

\section{DISCUSSION}

Plants interact with endophytic, symbiotic and exogenous microorganisms that have a profound influence on plants mostly because microbes are always at high numbers. Here we found that a considerable number of microorganisms live endophytically associated with roots, stems and leaves of soybean, suggesting that they are widespread within the plant. Furthermore, the plant genotype has a high impact on microorganisms' populations which is additionally influenced by plant management and the environment. Regarding this, Assumpção et al. (2009) found a greater diversity of endophytes within transgenic plants than within endophytes of conventional soybeans. Glyphosate-tolerant GM-soybean plant was genetically modified to tolerate exposure to glyphosate, thus application of glyphosate instead of traditional herbicides used in agronomic weed management might lead to changes in plantassociated microbial community as well as its activity and might also result in the synthesis and release of different quantity and composition of root and/or cell exudates (Motavalli et al. 2004). While studying endophytic bacteria isolated from soybeans grown in soils treated with glyphosate, Kuklinsky-Sobral et al. (2005) reported that also conventional soybeans contain low residue levels of glyphosate due to pre-planting applications. We already demonstrated that transgenic plants contain more diverse populations of endophytes than conventional 
cultivars (Almeida Lopes et al., 2016). In addition, it is interesting to note that Bacillus sp. and Burkholderia sp., the isolates with the highest antifungal activity towards fungi tested in this study, were found only in conventional soybean. Additional studies are needed to clarify if this is due to different weed management in conventional and GR soybean or to the effect of transgenesis on soybean plant and the associated microbial community. Whether transgenic or not, plants associate with a large community of microorganisms that live within plant tissues and this have a profund effect on plants. Such organisms are unique in that they are adapted to a quite distinct environment that protect microorganisms since they are less prone to quick changes in the environment because the plant intercellular spaces work as a homeostatic environment. The mechanisms of interaction between endophytic microorganisms and hosting plants is a key factor regarding the synthesis of specific compounds. This is such that could also affect the endophytes as a source of natural products (Strobel 2003). Furthermore, endophytes also produce and release plant growth regulators providing in this way advantages to the host plant, whose resistance to diseases is improved. Our results suggest that endophytic populations are influenced by plant genome as well as crop management. The latter is a factor with high impact on the microbial community, mainly due to the effect that application of agrochemicals might have on endophytes as demonstrated by Kuklinsky-Sobral et al. (2005). In this work we also studied the endophytic population of soybean plant as a source of organisms with different biotechnological potential.

Species belonging to genera such as Enterobacter, Bacillus, Burkholderia, Variovorax, Kosakonia were already reported as able to live endophytically (Yousaf et al., 2011; Gond et al., 2015; Correa-Galeote, 2018; Meng et al., 2015). Our isolates from soybean belonging to these genera were found to have antimicrobial activity towards several bacterial and fungal soybean pathogens. Kosakonia, that was also reported to live as 
endophytes in plants, was formerly referred as Enterobacter due to recent re-classification (Li et al., 2016; Brady et al., 2013). Two species that have also been found living as endophytes in plants were Serratia marcescens and Pantoea vagans. The latter one has also been described as epiphyte with an outstanding biocontrol capacity (Smits et al., 2010). Some of the isolates had a considerable level of antifungal activity in vitro, however extracts from these culture supernatants had no activity against the same fungi, suggesting that either there are two or more secreted molecules responsible of the antagonistic activity that are not precipitated or extracted together, which raises a question regarding the mechanism involved, or the need of a different in vivo mechanism, as could be the presence of the antagonized pathogen (Chanos and Mygind, 2016; Mela et al., 2011). Interestingly, it was also observed that bacterial strains, which lack activity against pathogen when tested alone, can act synergistically or as part of a microbial consortia (Mendes et al. 2011). This could be the case of some of the isolated endophytes that might slightly inhibit fungi in vitro, but when associated with other organisms and/or strains they promote growth (Jain et al., 2015). Additional experiments need to be performed to assess this possibility.

Different patterns of antimicrobial activity against microbial pathogens were observed when assays were perfomed either with the endophytes directly antagonizing the pathogen or using the extracts or precipitates from the same endophytes cell-free culture supernatants to control the pathogen. According to our results the use of extracts or precipitates from culture supernatants shows a stronger inhibitory activity towards pathogens than the bacteria in vitro. This could be due to higher concentration of antimicrobial molecules when extracted or precipitated from the supernatant.

Bacteria secrete many proteins, lipopeptides, or other molecules that are synthetized by different metabolic pathways, which might play a key role in control of plant diseases. There are procedures that can be used to selectively precipitate, extract and purify molecules 
that either promote plant growth or control pathogens such as ammonium sulfate precipitation and acidification and methanol or ethyl acetate extraction, followed by liquid chromatography (Vater et al. 2002; Hu et al. 2010; Yu et al. 2010; Malfanova et al., 2011; Rajan and Kannabiran 2014). B. subtilis produces iturin and fengycin of the lipopeptides family (Zhao et al., 2017) that were reported to control, among others, the fungus Podosphera fusca and to suppress the growth of Sclerotinia sclerotiorum (Romero et al., 2007). Although there is no experimental confirmation that our Bacillus sp. is a B. subtilis, its activity towards S. sclerotiorum and high similarity with B. subtilis 16SrRNA and rpoN genes suggest that it is most probably B. subtilis. More precisely our data suggested that it belongs to the $B$. subtilis species complex and, within this complex, to the $B$. amyloliquefaciens operational group. In this group there are several plant growth promoting bacteria such as B. amyloliquefaciens, B. velezensis and B. siamensis with high percentage of identity with our isolate. However precise identification of species within this group is difficult due to changes on the genomic level due to continuous development of life-style associated to plants (Fan et al., 2017).

Kang et al. (2004), studying the isolation and characterization of a Burkholderia strain (MSSP) that secretes an anti-fungal compound against $S$. sclerotiorum, found that the main mode of action of Burkholderia sp. in their studies of antagonism was to produce 2hydroxymethyl-chroman-4-one. Berić et al. (2012) screened 203 Bacillus isolates for antagonism against several phytopathogenic bacteria and found that all supernatants from Bacillus strain cultures had no activity against Pseudomonas aeruginosa. However, most of them had strong antimicrobial activity against Xanthomonas oryzae pv. oryzae, which showed radio of their inhibition zones ranging from 4 to $12 \mathrm{~mm}$, results similar to those found in this work. Monteiro et al. (2005) found that lipopeptides produced by Bacillus subtilis R14 were effective in controlling Xanthomonas campestris pv. campestris, causal 
agent of black rot of crucifers. In another study Zeriouh et al., (2011) suggested a key role of B. subtilis iturin in controlling bacterial pathogens such as Xanthomonas campestris pv. cucurbitae, while a lipopeptide from B. amyloliquefaciens supernatant was found to be antagonistic to Xanthomonas oryzae pv. oryzae (Li et al., 2016). Bacillus lipopeptides are linear or cyclic in nature, and concerning the antagonistic activity, three families, iturin, fengycin, and surfactin are the most important. Molecules belonging to these families frequently contain some amino acid residues (D-stereoisomers), which are unique and not commonly found in proteins, that are highly stable to $\mathrm{pH}$, heat, and proteolytic enzyme actvity (Kavitha et al. 2005). In addition, there are also some proteins that have also inhibitory effect. A protein secreted by B. subtilis strain SO113 was reported to have a broadspectrum of antimicrobial activity against $X$. oryzae pv. oryzae, including seven pathotypes of rice bacterial blight in China (Lin et al. 2001). Our study suggests that the isolated Bacillus sp. produces both types of molecules with antagonistic activity. Many strains of genus Bacillus and/or its metabolites are believed to be promising for an alternative or supplementary method to chemical plant protection (Pengnoo et al., 2000; Abanda-Nkpwatt et al., 2006). Bacillus spp. are among the most effective microbes in controlling various plant diseases and proved potentially useful tools as biocontrol agents (Nagorska et al. 2007).

Results presented in this study suggest that the identification of bacteria with antimicrobial activity should be achieved not only by screening the in vitro antagonism of the isolates towards the pathogen but also by testing the extracts and precipates from culture supernatant. Although in vitro antagonism not necessarily reflects the behaviour of the organisms in nature, in this study a preliminary screening was considered to reduce the total number of bacteria to be tested in the field conditions, as suggested by other authors (Lucon and Melo 1999). 
In conclusion, the results from this study indicate that many strains of bacterial endophytes isolated from soybean have strong anti-microbial activity against important soybean pathogens. Bacillus sp. and Burkholderia sp. were the most effective in controlling in vitro bacterial and fungal pathogens used in this study. Our results showed that the antagonistic activity is due to the synthesis of compounds mainly in isolates of the genus Bacillus and Burkholderia, suggesting that they have mainly peptidic origin if the antifungal activity is considered, while the antibacterial activity is relevant also in the organic solvent extracts, therefore suggesting the possible role played by secondary metabolites. Further experimental work on this topic will be of great interest. The available data concerning the biological control of these important soybean pathogens are very limited therefore these strains may be considered candidates for the development of inoculants for crop protection, although many technical, environmental and ecological factors influence the implementation of these strategies. Besides, research with endophytic bacteria instead of rhizobacteria provides a novel opportunity for discovery of new strains with biotechnological potential for being used as microbial inoculant.

\section{ACKNOWLEDGEMENTS}

This research was supported by CAPES - Science Without Borders Program (Coordenação de Aperfeiçoamento de Pessoal de Nível Superior) and by Fundação Araucária (Brazil). We thank ICGEB (International Centre For Genetic Engineering and Biotechnology) for the SMART Fellowship to Karla B. A. Lopes.

\section{CONFLICT OF INTEREST}

All authors state that there are no conflicts of interest deriving from the publication of this work. 


\section{REFERENCES}

Abanda-Nkpwatt, D., Krimm, U., Schreiber, L., Schwab, W. (2006) Dual antagonism of aldehydes and epiphytic bacteria from strawberry leaf surfaces against the pathogenic fungus Botrytis cinerea in vitro. BioControl 51, 279-291.

de Almeida Lopes K.B., Carpentieri-Pipolo V., Oro T.H., Pagliosa E. S., Degrassi G. (2016). Culturable endophytic bacterial communities associated with field grown soybean. $J$ Appl Microbiol. 3, 740-55.

Anzai, Y., Kudo, Y., Oyaizu, H. (1997) The phylogeny of the genera Chryseomonas, Flavimonas, and Pseudomonas supports synonymy of these three genera. Int J Syst Bacteriol. 47, 249-51.

Assumpção, L.C., Lacava, P.T., Dias, A.C.F., Azevedo, J.L., Menten, J.O.M. (2009) Diversidade e potencial biotecnológico da comunidade bacteriana endofítica de sementes de soja. Pesq Agropec Bras 44, 503-510.

Bae, H., Roberts, D.P., Lim, H-S., Strem, M.D., Park, S-C., Ryu, C-M., Melnick, R.L., Bailey, B.A. (2011) Endophytic Trichoderma isolates from tropical environments delay disease onset and induce resistance against Phytophthora capsici in hot pepper using multiple mechanisms. Mol Plant Microbe Interact 24, 336-351.

Balouiri, M., Sadiki, M., Ibnsouda, S.K. (2016) Methods for in vitro evaluating antimicrobial activity: A review. J Pharm Anal 6, 71-79.

Berg, G., and Hallmann, J. (2006) Control of plant pathogenic fungi with bacterial endophytes. In: Microbial root endophytes ed. Schulz, B., Boyle, C., Sieber, T.N. pp. 53-67. Berlin: Springer.

Berić, T., Kojić, M.O., Stanković, S., Topisirović, L.M., Degrassi, G., Myers, M., Venturi, V., Fira, D.A. (2012) Antimicrobial activity of Bacillus sp. natural isolates and their potential use in the biocontrol of phytopathogenic bacteria. Food Technology and Biotechnology 50, $25-31$.

Brady, C., Cleenwerck, I., Venter, S., Coutinho, T., De Vos, P. (2013). Taxonomic evaluation of the genus Enterobacter based on multilocus sequence analysis (MLSA): proposal to reclassify E. nimipressuralis and E. amnigenus into Lelliottia gen. nov. as Lelliottia nimipressuralis comb. nov. and Lelliottia amnigena comb. nov., respectively, E. gergoviae and E. pyrinus into Pluralibacter gen. nov. as Pluralibacter gergoviae comb. nov. and Pluralibacter pyrinus comb. nov., respectively, E. cowanii, E. radicincitans, E. oryzae and E. arachidis into Kosakonia gen. nov. as Kosakonia cowanii comb. nov., Kosakonia 
radicincitans comb. nov., Kosakonia oryzae comb. nov. and Kosakonia arachidis comb. nov., respectively, and E. turicensis, E. helveticus and E. pulveris into Cronobacter as Cronobacter zurichensis nom. nov., Cronobacter helveticus comb. nov. and Cronobacter pulveris comb. nov., respectively, and emended description of the genera Enterobacter and Cronobacter. Syst Appl Microbiol. 36, 309-19.

Chanos, P. and Mygind, T. (2016) Co-culture-inducible bacteriocin production in lactic acid bacteria. Appl Microbiol Biotechnol 100, 4297-4308.

Correa-Galeote, D., Bedmar, E.J., Arone, G.J. (2018). Maize endophytic bacterial diversity as affected by soil cultivation history. Front Microbiol. 9,484.

Dalal, J. and Kulkarni, N. (2013) Population dynamics and diversity of endophytic bacteria associated with soybean. British Microbiology Research Journal 3, 96-105.

Fan, B., Blom, J., Klenk, H.P., Borriss, R. (2017). Bacillus amyloliquefaciens, Bacillus velezensis, and Bacillus siamensis form an "operational group B. amyloliquefaciens" within the B. subtilis species complex. Front Microbiol. 8, 22.

Fravel, D.R. (2005) Commercialization and implementation of biocontrol. Annu Rev Phytopathol 43, 337-359.

Gond, S.K., Bergen, M.S., Torres, M.S., White, J.F. Jr. (2015). Endophytic Bacillus spp. produce antifungal lipopeptides and induce host defence gene expression in maize. Microbiol Res. 172,79-87.

Hynes, R.K. and Boyetchko, S.M. (2006) Research initiatives in the art and science of biopesticide formulations. Soil Biol Biochem 38, 845-849.

Hu, H.Q., Li, X.S., He, H. (2010) Characterization of an antimicrobial material from a newly isolated Bacillus amyloliquefaciens from mangrove for biocontrol of Capsicum bacterial wilt. Biological Control 54, 359-365.

Jain, A., Singh, A., Singh, S., Singh, H.B. (2015) Biological management of Sclerotinia sclerotiorum in pea using plant growth promoting microbial consortium. J Basic Microbiol. 55, 961-72.

Jamalizadeh, M., Etebarian, H.R., Aminian, H., Alizadeh, A. (2008) Biological control of gray mold on apple fruits by Bacillus licheniformis (EN74-1). Phytoparasitology 36, 23-29.

Kang, J.G., Shin, S.Y., Kim, M.J., Bajpai, V., Maheshwari, D.K., and Kang, S.C. (2004) Isolation and anti-fungal activities of 2-hydroxymethyl-chroman-4-one produced by Burkholderia sp. MSSP. J Antibiot 57, 726-731. 
Kavitha, S., Senthilkumar, S., Gnanamanickam, S.S., Inayathulla, M., Jayakumar, R. (2005) Isolation and partial characterization of an antifungal protein from Bacillus polymyxastrain VLB16. Process Biochem 40, 3236-3243.

Kearse, M., Moir, R., Wilson, A., Stones-Havas, S., Cheung, M., Sturrock, S., Buxton, S., Cooper, A., Markowitz, S., Duran, C., Thierer, T., Ashton, B., Mentjies, P., Drummond, A. (2012). Geneious Basic: an integrated and extendable desktop software platform for the organization and analysis of sequence data. Bioinformatics 28,1647-1649.

Koo, O.K., Eggleton, M., O'Bryan, C.A., Crandall, P.G., Ricke, S.C. (2012) Antimicrobial activity of lactic acid bacteria against Listeria monocytogenes on frankfurters formulated with and without lactate/diacetate. Meat Sci. 92, 533-537.

Kuklinsky-Sobral, J., Araújo, W.L., Mendes, R., Geraldi, I.O., Pizzirani-Kleiner A.A., Azevedo, J.L. (2004) Isolation and characterization of soybean-associated bacteria and their potential for plant growth promotion. Environ Microbiol 6, 1244-125.

Kuklinsky-Sobral, J., Araújo, W.L., Mendes, R., Pizzirani-Kleiner, A. A., Azevedo, J.L. (2005) Isolation and characterization of endophytic bacteria from soybean (Glycine max) grown in soil treated with glyphosate herbicide. Plant and Soil 273, 91-99.

Lane, D.J. (1991) 16S/23S rRNA sequencing. In Nucleic Acid Techniques in Bacterial Systematics ed. Stackebrandt, E. and Goodfellow, M. pp.115-175. Chichester: Wiley.

Li, C.Y., Zhou, Y.L., Ji, J., Gu, C.T. (2016) Reclassification of Enterobacter oryziphilus and Enterobacter oryzendophyticus as Kosakonia oryziphila comb. nov. and Kosakonia oryzendophytica comb. nov. Int J Syst Evol Microbiol 66, 2780-2783.

Li, S.B., Xu, S.R., Zhang, R.N., Liu, Y., Zhou, R.C. (2016) The antibiosis action and riceinduced resistance, mediated by a lipopeptide from Bacillus amyloliquefaciens B014, in controlling rice disease caused by Xanthomonas oryzae pv. oryzae. J Microbiol Biotechnol. 26,748-56.

Lin, D., Xu, Q., Liu, Y.Z., Wei, J.M., Qu, L.J., Gu, H.Y., Chen, Z.L. (2001) The antibacterial effect of the secreted peptide from Bacillus subtilis SO113 and separation and purification of the antibacterial peptides. J Agric Biotechnol 9, 77-80.

Lucon, C.M.M. and Melo, I.S. (1999) Seleção de rizobactérias antagônicas a Erwinia carotovora subsp. atroseptica, em tubérculos de batata. Summa Phytopathologica 25, 132136.

Maksimova, I.V., Abizgil'dinaa, R.R., Pusenkovab, L.I. (2011) Plant growth promoting rhizobacteria as alternative to chemical crop protectors from pathogens (Review). Appl Biochem Microbiol 47, 333-345.

This article is protected by copyright. All rights reserved. 
Malfanova N., Kamilova F., Validov S., Shcherbakov A., Chebotar V., Tikhonovich I., Lugtenberg B. (2011) Characterization of Bacillus subtilis HC8, a novel plant-beneficial endophytic strain from giant hogweed. Microbial Biotech 4, 523-532.

Mandal, S.M., Sharma, S., Pinnaka, A.K., Kumari, A., Korpole S. (2013) Isolation and characterization of diverse antimicrobial lipopeptides produced by Citrobacter and Enterobacter. BMC Microbiol., 13, 152-160.

Mela, F. Fritsche, K., de Boer, W., van Veen, J.A., de Graaff, L.H., van den Berg, M., Leveau, J.H.J. (2011) Dual transcriptional profiling of a bacterial/fungal confrontation: Collimonas fungivorans versus Aspergillus niger. The ISME J. 5, 1494-1504.

Melnick, R.L., Suárez, C., Bailey, B.A., Backman, P.A. (2011) Isolation of endophytic endospore forming bacteria from Theobroma cacaoas potential biological control agents of cacao diseases. Biol Control 57, 236-245.

Mendes, R., Kruijt, M., de Bruijn, I., Dekkers, E., van der Voort, M., Schneider, J.H., Piceno, Y.M., DeSantis, T.Z., Andersen, G.L., Bakker, P.A.H.M., Raaijmakers, J.M. (2011) Deciphering the rhizosphere microbiome for disease-suppressive bacteria. Science 332, 10971100 .

Meng, X., Bertani, I., Abbruscato, P., Piffanelli, P., Licastro, D., Wang, C., Venturi, V. (2015). Draft genome sequence of rice endophyte-associated isolate Kosakonia oryzae KO348. Genome Announc. 4, 3.

Mohammad, D., Jesus, M.B., Van Loon, L.C., Bakker, P.A.H.M. (2009) Analysis of determinants of Pseudomonas fluorescens WCS374r involved in induced systemic resistance in Arabidopsis thaliana. Biological control of fungal and bacterial plant pathogens 43, 109112.

Monteiro, L., Mariano, R.L.R., Souto-Maior, A.M. (2005) Antagonism of Bacillus spp. against Xanthomonas campestris pv. campestris. Braz arch biol technol 48, 23-29.

Montesinos, E. (2007) Antimicrobial peptides and plant disease control. FEMS Microbiol Lett 270, 1-11.

Motavalli, P.P., Kremer, R.J., Fang, M., Means, N.E. (2004) Impact of genetically modified crops and their management on soil microbially mediated plant nutrient transformations. $J$ Environ Qual 33, 816-824.

Nagorska, K., Bikowski, M., Obuchowskji, M. (2007) Multicellular behaviour and production of a wide variety of toxic substances support usage of Bacillus subtilis as a powerful biocontrol agent. Acta Biochim Pol 54, 495-508.

This article is protected by copyright. All rights reserved. 
Pengnoo, C., Kusongwiriyawong, C., Nilratana, L., Kanjanamaneesathian, M. (2000) Greenhouse and field trials of the bacterial antagonists in pellet formulations to suppress sheath blight of rice caused by Rhizoctonia solani, BioControl 45, 245-256.

Pimenta, R.S., Silva, J.F.M., Coelho, C.M., Morais, P.B., Rosa, C.A. (2010) Integrated control of Penicillium digitatum by the predacious yeast Saccharomycopsis crataegenesis and sodium bicarbonate on oranges. Braz J Microbiol 41, 404-410.

Rajan, B.M., Kannabiran, K. (2014) Extraction and identification of antibacterial secondary metabolites from marine Streptomyces sp. VITBRK2. Int J Mol Cell Med Summer 3, 130137.

Ramalingam, J., Savitha, P., Alagarasan, G., Saraswathi, R., Chandrababu, R. (2017). Functional marker assisted improvement of stable cytoplasmic male sterile lines of rice for bacterial blight resistance. Front Plant Sci. 8, 1131.

Romero, D., de Vicente, A., Rakotoaly, R.H., Dufour, S.E., Veening, J-W., Arrebola, E., Cazorla, F.M. Kuipers, O.P., Paquot, M., Pérez-García A. (2007). The iturin and fengycin families of lipopeptides are key factors in antagonism of Bacillus subtilis toward Podosphaera fusca. Mol. Plant Microbe Interact. 20, 430-440.

Rösch, C. and Bothe, H. (2005) Improved assessment of denitrifying, N2-fixing, and totalcommunity bacteria by terminal restriction fragment length polymorphism analysis using multiple restriction enzymes. Appl Environ Microbiol 71, 2026-2035.

Ryan RP, Germaine K, Franks A, Ryan DJ, Dowling DN. (2008). Bacterial endophytes: recent developments and applications. FEMS Microbiol Lett 278, 1-9.

Shi, B., Zheng, H., Huang, J., Luo, X., Luo, X. (2015) Purification and partial characterization of a thermostable antimicrobial protein from Bacillus subtilis FB123. World J Microbiol Biotechnol. 31,1285-90.

Smits, T.H., Rezzonico, F., Kamber, T., Goesmann, A., Ishimaru, C.A., Stockwell, V.O., Frey, J.E., Duffy, B. (2010) Genome sequence of the biocontrol agent Pantoea vagans strain C9-1. J Bacteriol 192, 6486-6487.

Smyth, T.J.P., Perfumo, A., McClean, S., Marchant, R., Banat, I.M. Isolation and analysis of lipopeptides and high molecular weight biosurfactants. In: Timmis KN, ed. Handbook of hydrocarbon and lipid microbiology. Berlin: Springer; (2010) p. 3689-3704.

Soundra Josephine, F., Ramya, V.S., NelamDevi, Suresh Babu Ganapa, Siddalingeshwara K.G., Venugopal, N., Vishwanatha, T. (2012) Isolation, production and characterization of protease from Bacillus sp. isolated from soil sample. J Microbial Biotech Res 2, 163-168.

This article is protected by copyright. All rights reserved. 
Strobel, G.A. (2003) Endophytes as sources of bioactive products. Microbes Infect. 5, 53544.

Syed Ab Rahman, S.F., Singh, E., Pieterse, C.M.J., Schenk, P.M. (2018). Emerging microbial biocontrol strategies for plant pathogens. Plant Sci. 267, 102-111.

Taghavi, S., Garafola, C., Monchy, S., Newman, L., Hoffman, A., Weyens, N., Barac, T., Vangronsveld, J., Van der Lelie, D. (2009) Genome survey and characterization of endophytic bacteria exhibiting a beneficial effect on growth and development of poplar trees. Appl Environ Microbiol 75, 748-757.

Vater, J., Kablitz, B., Wilde, C., Franke, P., Mehta, N., Cameotra, S.S. (2002) Matrix-assisted laser desorption ionization-time of flight mass spectrometry of lipopeptide biosurfactants in whole cells and culture filtrates of Bacillus subtilis C-1 isolated from petroleum sludge. Appl Environ Microbiol 68, 6210-6219.

Verhagen, B.W.M., Trotel-Aziz, P., Couderchet, M., Hofte, M., Aziz, A. (2010) Pseudomonas spp.-induced systemic resistance to Botrytis cinerea is associated with induction and priming of defense responses in grapevine. $J$ Exp Bot 61, 249-260.

Xing, D., Ren, N., Wang, A., Li, Q., Feng, Y., Ma, F. (2008) Continuous hydrogen production of auto-aggregative Ethanoligenens harbinense YUAN-3 under non-sterile condition. International Journal of Hydrogen Energy 33, 1489-1495.

Yousaf, S., Afzal, M., Reichenauer, T.G., Brady, C.L., Sessitsch, A. (2011). Hydrocarbon degradation, plant colonization and gene expression of alkane degradation genes by endophytic Enterobacter ludwigii strains. Environ Pollut.159, 2675-83.

Yu H., Zhang L., Li L., Zheng C., Guo L., Li W., Sun P., Qin L. (2010) Recent developments and future prospects of antimicrobial metabolites produced by endophytes. Microbiol Res $165,437-49$.

Zeriouh, H., Romero, D., Garcia-Gutierrez, L., Cazorla, F.M., de Vicente, A., Perez-Garcia, A. (2011). The iturin-like lipopeptides are essential components in the biological control arsenal of Bacillus subtilis against bacterial diseases of cucurbits. Mol Plant Microbe Interact. 24, 1540-52.

Zhao, H., Shao, D., Jiang, C., Shi, J., Li, Q., Huang, Q., Rajoka, M.S.R., Yang, H., Jin, M. (2017). Biological activity of lipopeptides from Bacillus. Appl Microbiol Biotechnol. 101, 5951-5960.

Zinniel, D.K., Lambrecht, P., Harris, N.B., Feng, Z., Kuczmarski, D. Higley, P., Ishimaru, C.A., Arunakumari, A., Barletta, R.G., Vidaver, A.K. (2002) Isolation and characterization of 
endophytic colonizing bacteria from agronomic crops and prairie plants. Appl and Environ Microbiol 68, 2198-2208.

Table 1. In vitro antagonistic activity of endophytic bacterial isolates from soybean against the soybean pathogens $S$. sclerotiorum $(\mathrm{S})$, P. sojae $(\mathrm{P})$, R. solani $(\mathrm{R})$, X. axonopodis pv. glycines IBSBF327 and IBSBF333 (61Xag and 62Xag, respectively) and P. savastanoi pv. glycinea IBSBF355 (60Psg).

\begin{tabular}{|c|c|c|c|c|c|c|c|c|c|c|}
\hline Isolate & ID & Possible species & Cultivar & Tissue & S. sclerotiorum & P. sojae & $\begin{array}{c}\text { R. } \\
\text { solani }\end{array}$ & $61 X a g$ & $62 X a g$ & 60Psg \\
\hline 1 & 226 & Enterobacter ludwigii & $\mathrm{C}$ & Root & ++ & - & - & + & - & - \\
\hline 2 & 231 & Enterobacter sp. & $\mathrm{C}$ & Root & + & - & - & - & - & - \\
\hline 3 & 219 & Enterobacter sp. & $\mathrm{C}$ & Root & + & - & - & - & - & - \\
\hline 4 & 179 & $\begin{array}{l}\text { Agrobacterium tumefaciens / } \\
\text { Rhizobium sp. }\end{array}$ & GR & Stem & + & - & - & - & - & - \\
\hline 5 & 79 & Kosakonia cowardii & GR & Leave & + & - & - & - & - & - \\
\hline 6 & 41 & Variovorax sp. & $\mathrm{C}$ & Root & ++ & - & - & - & - & - \\
\hline 7 & 152 & Bacillus sp. & $\mathrm{C}$ & Stem & +++ & - & - & - & - & - \\
\hline 8 & 137 & Burkholderia sp. & $\mathrm{C}$ & Root & +++ & +++ & +++ & - & - & - \\
\hline 9 & 130 & Burkholderia sp. & $\mathrm{C}$ & Root & +++ & - & +++ & - & - & - \\
\hline 10 & 243 & Burkholderia sp. & $\mathrm{C}$ & Root & +++ & +++ & - & - & - & - \\
\hline 11 & 106 & Pantoea vagans & GR & Leave & + & - & - & - & - & - \\
\hline 12 & 245 & Serratia marcescens & GR & Leave & ++ & - & - & - & - & - \\
\hline 13 & 110 & Enterobacter sp. & GR & Root & + & - & - & - & - & - \\
\hline
\end{tabular}

Activity antagonism: Classification of isolates according to the size of the halo, where: (-) no halo or no activity; $(+)$ small halo (1-2 mm), little activity; $(++)$ medium halo $(3-4 \mathrm{~mm})$, median activity; $(+++)$ large halo (above 4 $\mathrm{mm})$, high activity. Cultivars: $\mathrm{C}$ - non-transgenic soybean; GR - glyphosate-resistant transgenic soybean.

This article is protected by copyright. All rights reserved. 
Table 2. Antimicrobial activity of methanol extract $(\mathrm{MeOH})$, ammonium sulfate precipitate (NH4-S), and ethyl acetate extract (EtAc) from cell-free culture supernatant of endophytic bacteria tested on soybean fungal pathogens.

\begin{tabular}{|c|c|c|c|c|c|c|c|c|c|c|}
\hline Isolate & $\begin{array}{l}\text { Possible } \\
\text { species }\end{array}$ & $\begin{array}{r}S . s c \\
M e O H\end{array}$ & $\begin{array}{l}\text { lerotior } \\
\text { NH4-S }\end{array}$ & EtAc & $\mathrm{MeOH}$ & $\begin{array}{l}\text { sojae } \\
\text { NH4-S }\end{array}$ & $E t A c$ & $\stackrel{R}{\mathrm{MeOH}}$ & $\begin{array}{l}\text { solani } \\
\text { NH4-S }\end{array}$ & EtAc \\
\hline 1 & $\begin{array}{l}\text { Enterobacter } \\
\text { ludwigii }\end{array}$ & - & - & +++ & - & - & - & - & - & - \\
\hline 2 & $\begin{array}{l}\text { Enterobacter } \\
\text { sp. }\end{array}$ & - & - & - & - & - & + & - & - & - \\
\hline 3 & $\begin{array}{l}\text { Enterobacter } \\
\text { sp. } \\
\text { Agrobacterium }\end{array}$ & - & - & - & - & - & - & - & - & - \\
\hline 4 & $\begin{array}{l}\text { tumefaciens / } \\
\text { Rhizobium sp. }\end{array}$ & - & - & - & - & - & - & - & - & - \\
\hline 5 & $\begin{array}{l}\text { Kosakonia } \\
\text { cowardii }\end{array}$ & - & - & - & - & - & - & - & - & - \\
\hline 6 & Variovorax sp. & + & + & - & + & + & - & - & - & - \\
\hline 7 & Bacillus sp. & +++ & +++ & +++ & +++ & +++ & - & +++ & +++ & - \\
\hline 8 & $\begin{array}{l}\text { Burkholderia } \\
\text { sp. }\end{array}$ & +++ & +++ & +++ & +++ & +++ & + & +++ & +++ & + \\
\hline 9 & $\begin{array}{l}\text { Burkholderia } \\
\text { sp. }\end{array}$ & +++ & +++ & +++ & +++ & +++ & +++ & +++ & +++ & ++ \\
\hline 10 & $\begin{array}{l}\text { Burkholderia } \\
\text { sp. }\end{array}$ & +++ & +++ & - & +++ & +++ & +++ & +++ & +++ & ++ \\
\hline 11 & $\begin{array}{l}\text { Pantoea } \\
\text { vagans }\end{array}$ & - & - & - & - & - & ++ & - & - & - \\
\hline 12 & $\begin{array}{l}\text { Serratia } \\
\text { marcescens }\end{array}$ & + & ++ & - & + & + & - & - & - & - \\
\hline 13 & $\begin{array}{l}\text { Enterobacter } \\
\text { sp. }\end{array}$ & - & - & - & - & - & - & - & - & - \\
\hline
\end{tabular}

Antimicrobial activity: (-) no pathogen growth inhibition; (+) up to 35\% inhibition; (++) between 35 and $70 \%$ inhibition; $(+++)$ more than $70 \%$ inhibition.

This article is protected by copyright. All rights reserved. 
Table 3. Antimicrobial activity of cell-free culture supernatant of endophytic bacteria isolated from soybean extracted with methanol $(\mathrm{MeOH})$, precipitated with ammonium sulfate (NH4-S), and extracted with ethyl acetate (EtAc), tested on soybean bacterial pathogens.

\begin{tabular}{|c|c|c|c|c|c|c|c|c|c|c|}
\hline Isolate & $\begin{array}{l}\text { Possible } \\
\text { species }\end{array}$ & МeOH & $\begin{array}{l}\text { 61Xag } \\
\text { NH4-S }\end{array}$ & $E t A c$ & $\mathrm{MeOH}$ & $\begin{array}{l}\text { 62Xag } \\
\text { NH4-S }\end{array}$ & $E t A c$ & $\mathrm{MeOH}$ & $\begin{array}{l}\text { 60Psg } \\
\text { NH4-S }\end{array}$ & $E t A c$ \\
\hline 1 & $\begin{array}{l}\text { Enterobacter } \\
\text { ludwigii }\end{array}$ & - & - & - & - & - & - & - & - & - \\
\hline 2 & $\begin{array}{l}\text { Enterobacter } \\
\text { sp. }\end{array}$ & - & - & - & - & - & - & - & - & - \\
\hline 3 & $\begin{array}{l}\text { Enterobacter } \\
\text { sp. } \\
\text { Agrobacterium }\end{array}$ & - & - & - & - & - & - & - & - & - \\
\hline 4 & $\begin{array}{l}\text { tumefaciens / } \\
\text { Rhizobium sp. }\end{array}$ & - & - & - & - & - & - & - & - & - \\
\hline 5 & $\begin{array}{l}\text { Kosakonia } \\
\text { cowardii }\end{array}$ & - & - & - & - & - & - & - & - & - \\
\hline 6 & Variovorax sp. & - & - & - & - & - & - & - & - & - \\
\hline 7 & Bacillus sp. & ++ & +++ & ++ & ++ & +++ & - & + & ++ & +++ \\
\hline 8 & $\begin{array}{l}\text { Burkholderia } \\
\text { sp. }\end{array}$ & - & - & - & - & - & - & - & - & - \\
\hline 9 & $\begin{array}{l}\text { Burkholderia } \\
\text { sp. }\end{array}$ & - & ++ & ++ & - & ++ & + & - & - & +++ \\
\hline 10 & $\begin{array}{l}\text { Burkholderia } \\
\text { sp. }\end{array}$ & + & - & +++ & + & - & +++ & - & - & +++ \\
\hline 11 & Pantoea vagans & - & - & + & - & - & - & - & - & - \\
\hline 12 & $\begin{array}{l}\text { Serratia } \\
\text { marcescens }\end{array}$ & - & - & - & - & - & - & - & - & - \\
\hline 13 & $\begin{array}{l}\text { Enterobacter } \\
\text { sp. }\end{array}$ & - & - & - & - & - & - & - & - & - \\
\hline
\end{tabular}

Antimicrobial activity: (-) no pathogen growth inhibition; (+) inhibition halo up to $4 \mathrm{~mm}$; $(++)$ inhibition halo from 4 to $8 \mathrm{~mm}$; (+++) inhibition halo more than $8 \mathrm{~mm}$.

This article is protected by copyright. All rights reserved. 


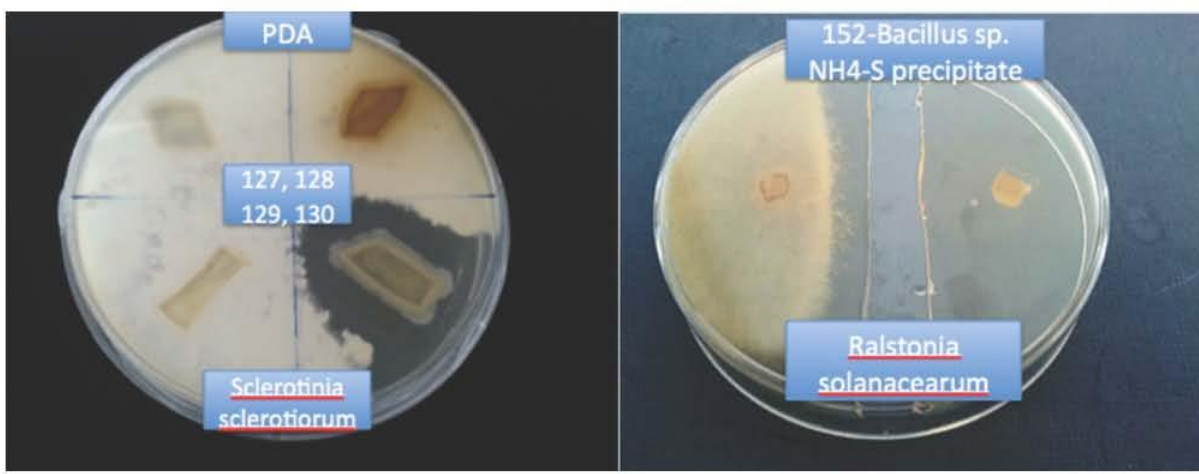

2 A

B $\quad 1$

2

3 Figure 1. A - In vitro antagonistic activity of endophytic bacteria, recovered from different 4 tissues of soybean, against the fungal pathogen S. sclerotiorum grown on PDA. Isolate 130 is

5 Burkholderia sp 9. Isolates 127, 128 and 129 are isolates without antimicrobial activity. B - In 6 vitro antifungal activity of compounds from culture supernatant of isolate 152, Bacillus sp. 7 ,

7 (2) and from the medium only (1) precipitated by ammonium sulfate.

8

9

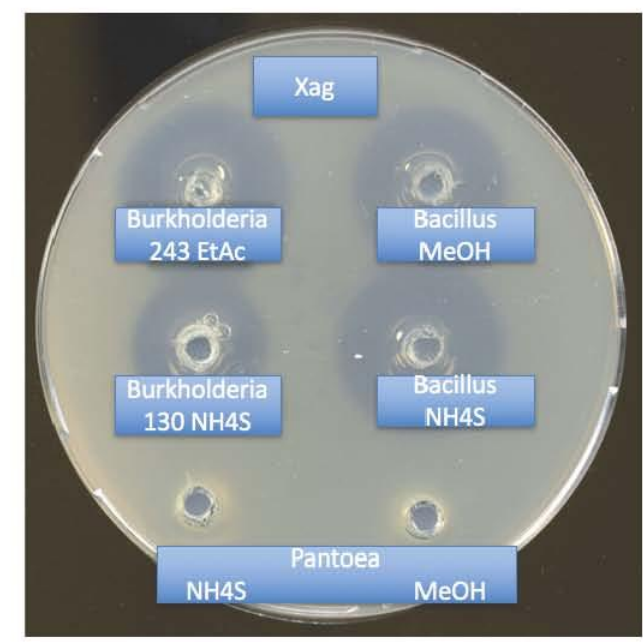

10 Figure 2. In vitro antagonistic activity of some extracts from culture supernatants of endophytic 11 bacteria recovered from different tissues of soybean, against $X$. axonopodis pv glycines. $\mathrm{MeOH}$, 12 EtAc and NH4S indicate extraction with methanol, ethyl acetate or precipitation with 13 ammonium sulfate, respectively. 
15

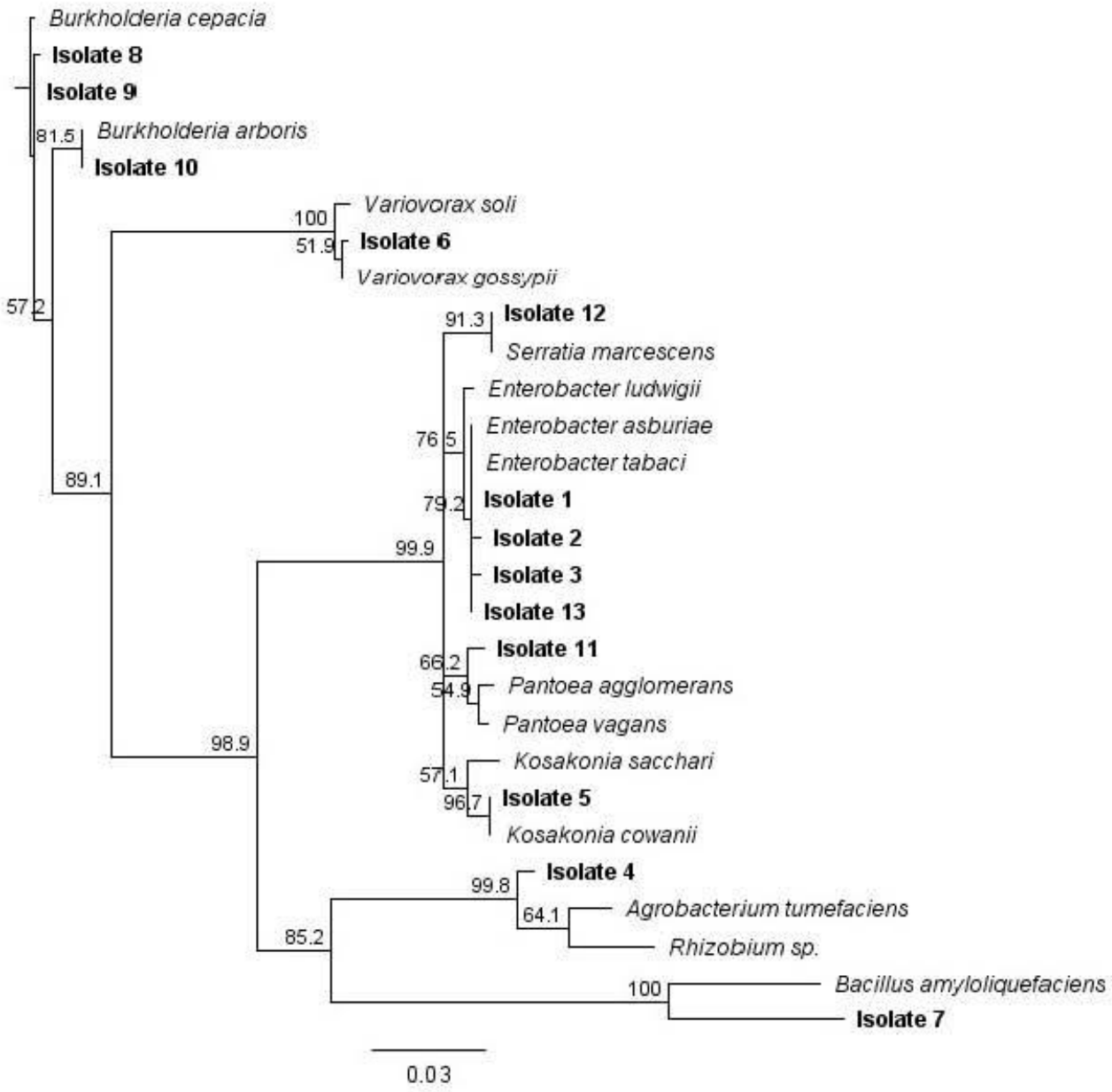

Figure 3A. Neighbor-joining phyl ogenetic tree based on 16 SrRNA gene, was constructed using the partial nucleotide sequence of the endophytic bacteria that present antimicrobial activity to soybean patogens. Node labels refers to bo otstrap support ( $N=1000$ replicates). 


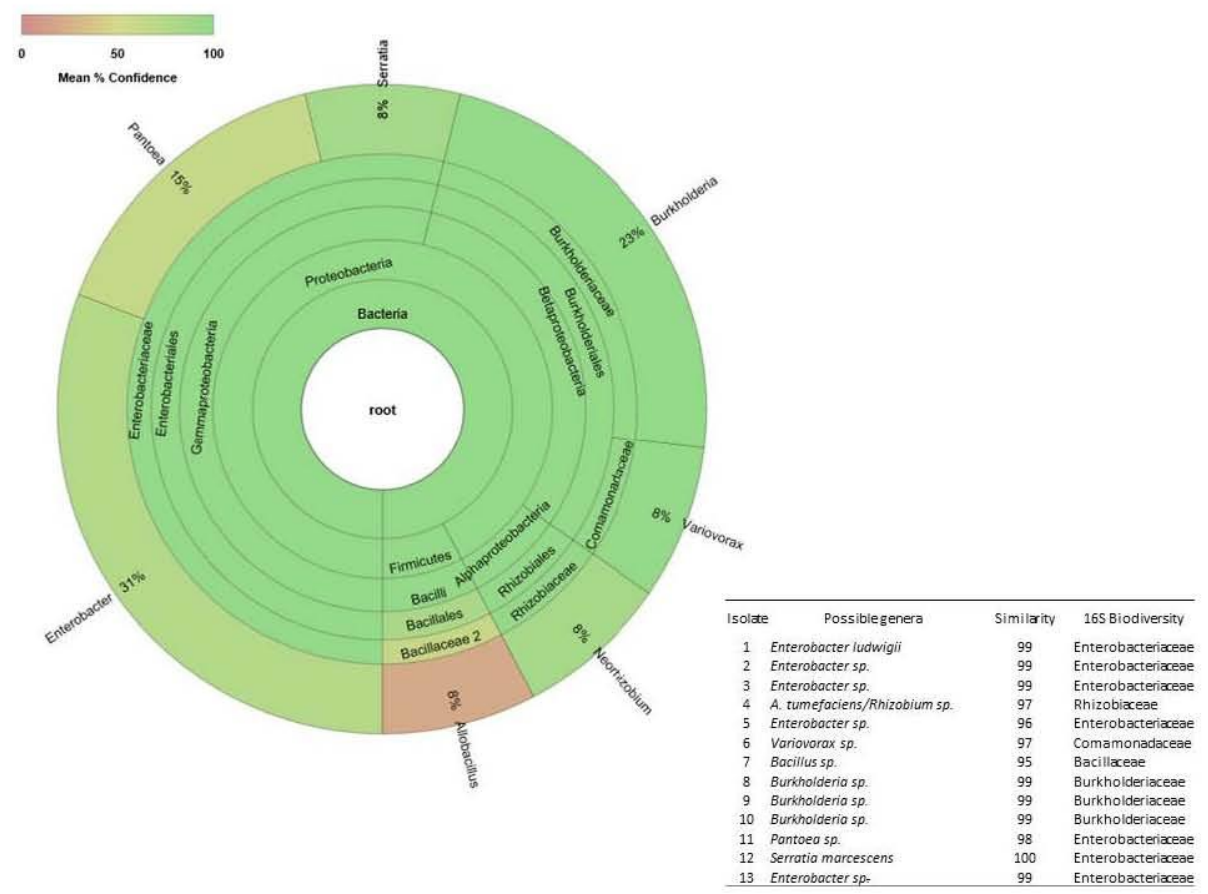

22 Figure 3B. Endophytic bacteria isolated from soybean identified based on the $16 \operatorname{SrRNA}$

23 amplicon sequence and homology with type strains sequences. The figure was built with the

24 cloud-based 16SrRNA biodiversity tool [Geneious version R9.0, (Biomatters,

$25 \mathrm{http} / /$ www.geneious.com, Kearse et al. 2012)]. The color type and intensity indicates the mean confidence value found in the analysis (Green 100\% and Redish-brown 0\%). The percentage at the right side of each genus indicates the $\%$ of isolates belonging to that genus. The list of isolates, $\%$ of similarity to type strain sequence as well as the family they belong to, are

29 presented in the table included at the right bottom end of the figure. 


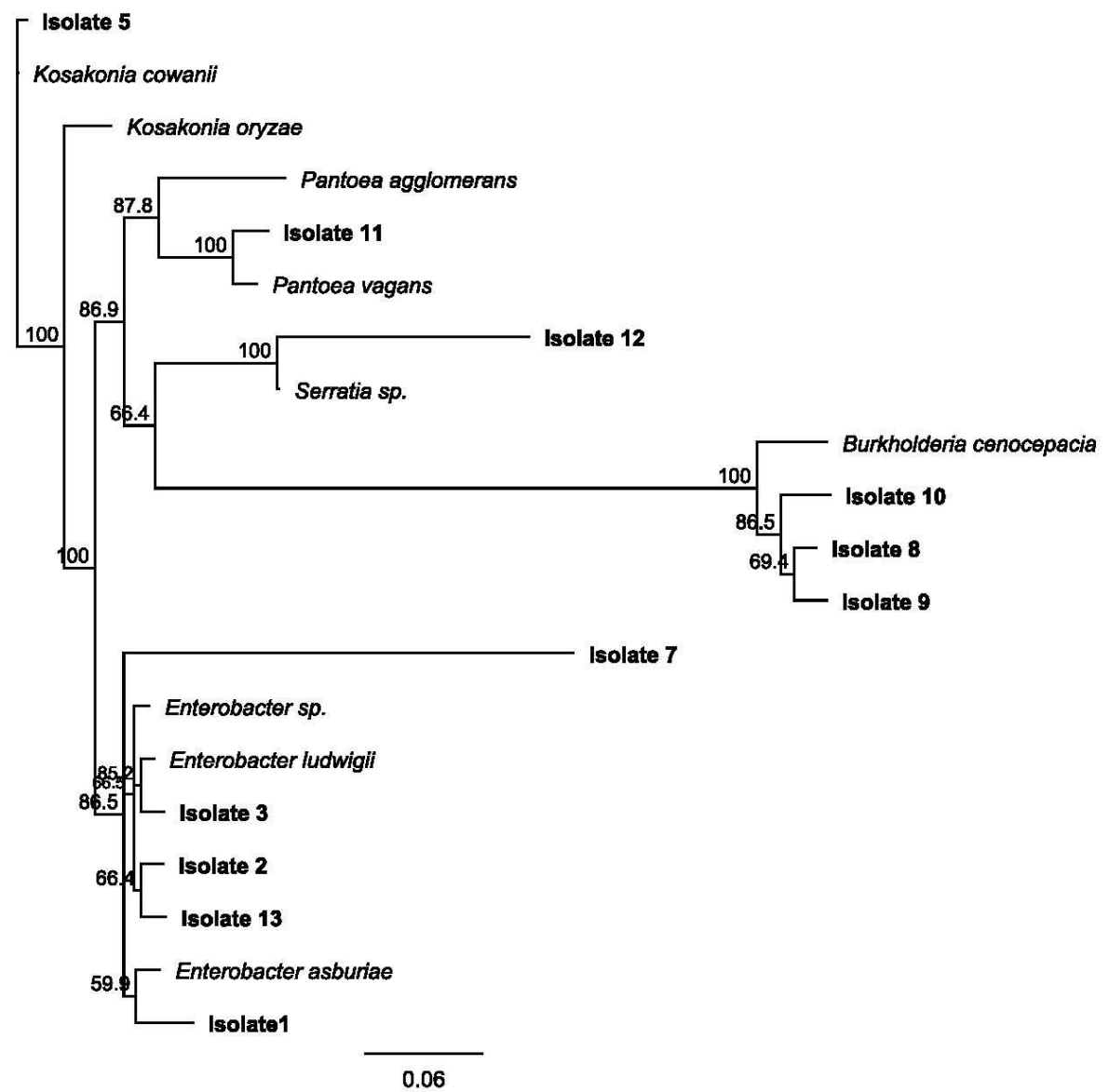

31 Figure 4. Neighbor-joining phylogenetic tree based on $r p o N$ gene sequence. The tree was 32 contructed using the partial nucleotide sequence of the endophytic bacteria that present 33 antimicrobial activity to soybean patogens (Geneious software version 9.0, 34 www.geneious.com). Node labels refers to bootstrap support ( $\mathrm{N}=1000$ replicates).

This article is protected by copyright. All rights reserved. 


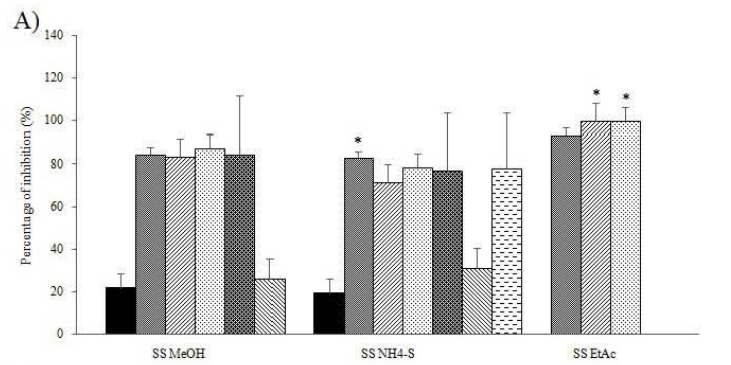

EEnterobacter ludwigii 1

- Variovorax sp. 6

$\square$ Bacillus sp. 7

Burkholderia cenocepacia 8

Burkholderia cenocepacia 9

圈 Burkholderia cenocepacia 10

$\mathbb{\Delta}$ Serratia marcescens 12

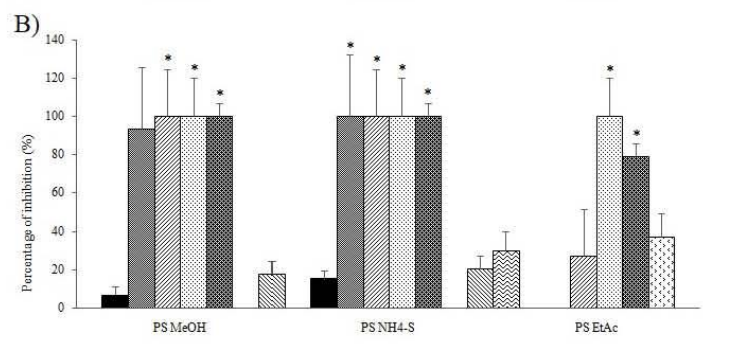

Enterobacter sp. 2

- Variovorax sp. 6

$\square$ Bacillus sp.

Burkholderia cenocepacia 8

: Burkholderia cenocepacia 9

Burkholderia cenocepacia 10

Pantoea vagans 11

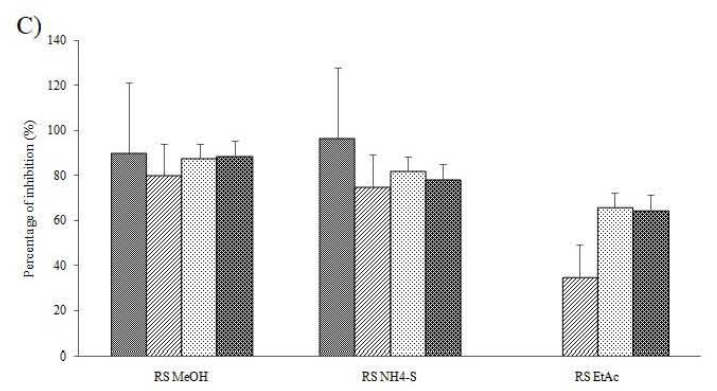

$\square$ Bacillus sp. 7

Burkholderia cenocepacia 8

Burkholderia cenocepacia 9

鲕Burkholderia cenocepacia 10

Figure 5. Antagonistic activity of cell-free culture supernatant of endophytic bacteria recovered

40 from soybean, extracted with methanol $(\mathrm{MeOH})$, precipitated with ammonium sulfate (NH4-S)

or extracted with ethylacetate (EtAc) against: A, S. sclerotiorum (SS), B, P. sojae (PS), and C,

42 R. solani (RS). Error bar indicates SD length. Asterisk (*) over error bar indicates significance

43 at $\mathrm{t}$ Test $(\mathrm{p}=0,05 \%)$.

This article is protected by copyright. All rights reserved. 


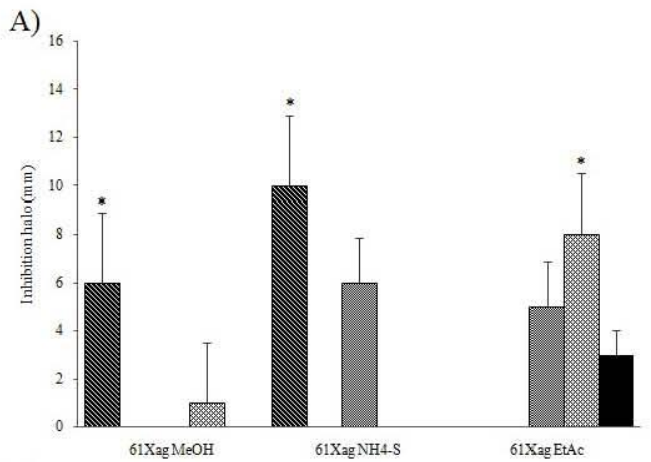

Bacillus sp. 7

$\square$ Burkholderia cenocepacia 8

- Burkholderia cenocepacia 9

Burkholderia cenocepacia 10

- Pantoea vagans 11

B)

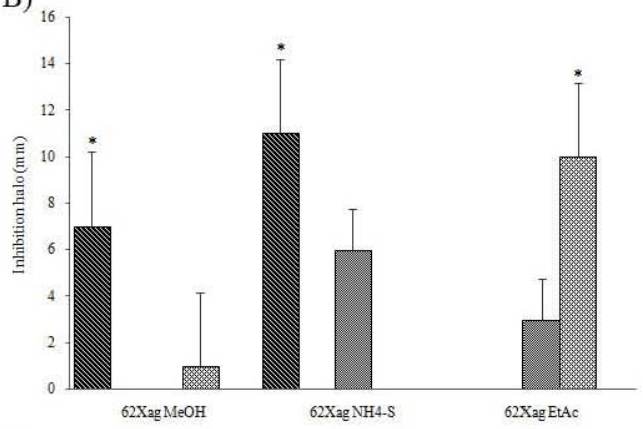

$\mathbb{B}$ Bacillus sp. 7

$\square$ Burkholderia cenocepacia 8

$\square$ Burkholderia cenocepacia 9

Burkholderia cenocepacia 10

- Pantoea vagans 11

C)

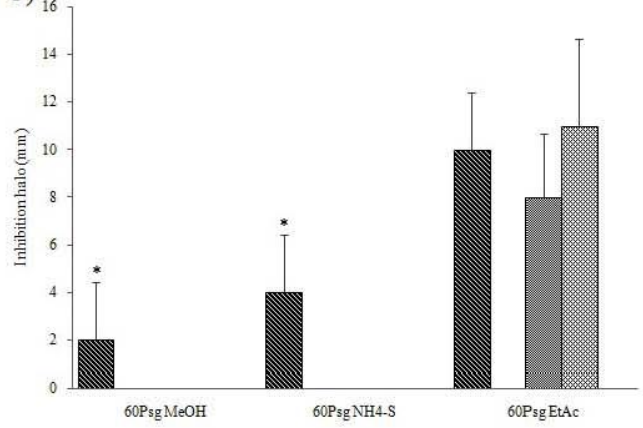

$\mathbb{B}$ Bacillus sp. 7

$\square$ Burkholderia cenocepacia 8

$\square$ Burkholderia cenocepacia 9

四 Burkholderia cenocepacia 10

- Pantoea vagans 11

Figure 6. Antagonistic activity of cell-free culture supernatant of endophytic bacteria recovered from soybean, extracted with methanol $(\mathrm{MeOH})$, precipitated with ammonium sulfate (NH4-S) or extracted with ethyl acetate (EtAc) against: A, $X$. axonopodis pv. glycines IBSBF327 (61Xag), B, X. axonopodis pv. glycines IBSBF333 (62Xag) and C, P. savastanoi pv. glycinea IBSBF355 (60Psg). Error bar indicates SD length. Asterisk $\left(^{*}\right)$ over error bar indicates significance at $t$ Test $(\mathrm{p}=0,05 \%)$. 